\title{
A Conceptual and Methodological Framework of Leisure Activity Loyalty Accommodating the Travel Context
}

\author{
Jeffrey J. LaMondia \\ Auburn University \\ Department of Civil Engineering \\ 238 Harbert Engineering Center \\ Auburn, AL 36849-5337 \\ Phone: 334-844-6284; Fax: 334-844-6290 \\ E-mail: jlamondia@auburn.edu \\ and \\ Chandra R. Bhat \\ The University of Texas at Austin \\ Dept of Civil, Architectural and Environmental Engineering \\ 1 University Station C1761 \\ Austin, TX 78712-0278 \\ Phone: 512-471-4535, Fax: 512-475-8744 \\ E-mail: bhat@mail.utexas.edu
}

April 18, 2011 


\begin{abstract}
As leisure travel continues to grow, it has become a critical subject for planners and decisionmakers since it significantly impacts regional economic and social development as well as contributes to emission levels and congestion. Despite being a significant percentage of our travel, however, leisure travel behavior is still not very well understood. The goal of this paper is to contribute to our understanding of leisure activity participation by considering leisure activity loyalty within the travel context. In particular, this study focuses on one specific dimension of travel context: travel extent (i.e. whether an individual participates in a leisure activity on a daily versus a long-distance basis). As such, this paper first introduces a unified conceptual framework for measuring leisure activity loyalties within a travel context, based on two distinct dynamics of leisure loyalty behavior - destination attachment and activity involvement. Additionally, this paper uses a unique 2001 NHTS dataset comprised of households' daily and long-distance leisure activities to undertake a unique empirical analysis of five distinct leisure activities using the conceptual framework and a copula-based model methodology. The findings confirmed that households demonstrate significant loyalties to travel contexts across all leisure activities, especially resting and sightseeing.
\end{abstract}

Keywords: Leisure travel behavior, leisure activity loyalty, copula approach, ordered-response model. 


\section{INTRODUCTION}

Leisure travel, broadly defined as travel to visit friends and relatives, for outdoor recreation, and for entertainment and other non-maintenance personal activities, "accounts for the majority (75\%) of all US (long-distance, home-based) domestic trips", in terms of both the number of trips (US Travel Association, 2005) as well as the vehicle miles traveled (Schlich et al., 2004). Over the past few decades, improved technology, faster information dissemination, expanded social networks, and increased available leisure time budgets has further contributed to the rise of leisure activities and associated trip-making among US households. In fact, leisure travel has become ingrained into US households' way of life, with many households routinely making both daily short-distance leisure trips and long-distance vacation trips (Bargeman and van der Poel, 2006). US households made over 1.5 billion leisure person-trips in 2008, and the number of leisure trips continues to grow despite the recent downturn in the economy and hikes in fuel prices (Holecek and White, 2007 and US Travel Association, 2008).

Not surprisingly, leisure travel has become a critical subject of analysis for planners and decision-makers since it significantly impacts regional economic and social development (Limtanakool et al., 2006), as well as contributes to emission levels and regional congestion (Schlich et al., 2004). Thus, researchers have strived to better understand leisure travel behavior to improve transportation policies, and inform infrastructure and land development decisions. At the same time, researchers realize the many challenges in modeling and predicting leisure travel. For instance, leisure trips are generally less obligatory than typical maintenance activities, have more variety in purpose and location of participation, may not be pursued regularly, and peak toward evenings and weekends (Kemperman et al., 2006, Brey and Lehto, 2007, Lockwood et al., 2005). Indeed, it is perhaps because of this inherent variety and less regularity of participation of individuals and households that, despite being a significant percentage of our travel, leisure travel behavior is still not very well understood.

Despite the variety seeking and irregular nature of leisure activities, individuals still develop leisure preferences, routines and habits over extended periods of time, similar to nonleisure travel behavior. Researchers have shown that individuals often repeatedly participate in specific leisure activities or visit specific leisure destinations when they have the opportunity to do so. Furthermore, repeat leisure activity participation can even extend across daily and longdistance settings, depending on individuals' level of interest (Brey and Lehto, 2007). It is, 
therefore, valuable to consider activity participation over longer periods of time to fully understand leisure travel behavior. While studies of activity participation at a single destination or during a single trip can provide insights into leisure travel decision-making, it is the studies of activity loyalty that are most effective at capturing how travelers develop their leisure activity preferences over longer periods of time. Studies suggest that such leisure preferences and habit formation are closely tied to the concept of leisure loyalty, commonly defined as "a biased behavior expressed over time by an individual with respect to one or more alternatives that is a function of psychological processes" (Jacoby and Kyner, 1973, Bargeman and van der Poel, 2006).

When discussing leisure activities, it is particularly important for several application, conceptual, and methodological reasons to consider the role of loyalty. First, travelers who are loyal to specific leisure activities or destinations are significantly more likely to select destinations in which they can participate in those activities during their "free time". Additionally, these loyal individuals are much less sensitive to changes in costs and policies associated with those leisure activities (see, for example, Shoemaker and Lewis, 1999, Alegre and Juaneda, 2006, McMullan and Gilmore, 2008). By identifying the activity loyalties of travelers, city and tourism planners can develop destination activities and adopt appropriate policies and price-points to effectively retain current visitors as well as attract new visitors. Second, while researchers recognize the considerable impact that loyalties have on leisure travel behavior, the nuances of these effects are relatively unexplored (Schlich et al., 2004). In particular, there is a lack of a clear, unified conceptual understanding of leisure loyalty (Bandyopadhyay and Martell, 2007, Lee et al., 2007), as well as limited empirical analysis of leisure loyalty behavior (due in part to the difficulty in collecting data and proper methods of analysis; Bargeman et al., 2002). Third, both a better understanding of sensitivities as well as a conceptual framework can improve methodologies for predicting and planning for individuals' travel patterns. For example, there are many opportunities to improve the methods of scheduling and selecting between leisure activities in activity-based models of travel behavior.

Perhaps even more importantly, there is inadequate consideration of the travel context in existing leisure loyalty research. Travel contexts describe the defining interrelated conditions in which travel decisions occur. For instance, travel contexts may include factors such as perceived travel times, connection to social networks, ease and convenience of travel, accessibility to 
destination, intrinsic recreation value of travel, personal association with destination and/or activity, travel extent (i.e. typical daily or unique longer distance), and traffic conditions. In fact, leisure activity involvement has become highly situational, heightened by specific travel context instances or circumstances (Gahwiler and Havitz, 1998, Brey and Lehto, 2007)). As a result, individuals have become loyal to activities within a specific travel context (Lee et al., 2007). The fact that individuals choose sometimes to travel longer distances to participate in activities that they could very well pursue closer to home implies that the travel context of leisure activity participation needs due consideration when studying leisure loyalties and leisure activity participations. Surprisingly, travel contexts have not been previously included in studies of loyalty or leisure activities.

The goal of this paper is to contribute to our understanding of leisure activity participation by considering leisure activity loyalty within the travel context. In particular, this study focuses on one specific dimension of travel context: travel extent (i.e. whether an individual participates in a leisure activity on a daily versus a long-distance basis). This context was selected because while much of the current literature recognizes that leisure travel behavior and activity participation vary significantly depending on the trip extent, these differences have not been thoroughly studied (please refer to Gahwiler and Havitz, 1998; Brey and Lehto, 2007; Lee et al., 2007). As such, this paper first introduces a unified conceptual framework for measuring leisure activity loyalties within a travel context, based on two distinct dynamics of leisure loyalty behavior - destination attachment and activity involvement. Additionally, this paper undertakes a unique empirical analysis of five distinct leisure activities using the conceptual framework and a copula-based model methodology.

The paper is structured as follows: The next section discusses the destination satisfaction and activity involvement elements of leisure loyalty. Section 3 introduces the travel contextbased loyalty framework. Section 4 presents the data source and sample used for the empirical analysis in the paper. Section 5 details the copula-based ordered probit methodology. Empirical results are discussed in Section 6, and Section 7 discusses planning applications as well as conceptual and methodological implications. 


\section{DEFINING AND MEASURING LOYALTY}

Leisure activity loyalty is defined by two complementary dynamics: individuals' attachment to destinations and their involvement in activities. Destination attachment reasons that as individuals participate in activities at similar types of locations, they develop an emotional connection with those locations. Activity involvement further supposes that as individuals become more active in specific activities, they become specialized in those activities. Together, these emotional connections and specializations lead to activity loyalty. Unfortunately, neither dynamic fully considers the role of travel contexts, as we discuss in the subsequent sections.

\subsection{Loyalty through Destination Attachment}

The theory of destination attachment states that travelers repeatedly visit similar types of destinations because they form a relationship with these locations (Yoon and Uysal, 2005). This relationship is based on individuals' continued satisfaction with destinations (i.e. whether expectations are consistent with their experiences and final destination image) (Petrick, 2005, Hernandez-Lobato et al., 2006, Lam and Hsu, 2006, Castro et al., 2007). As individuals build stronger relationships over time, they become more personally and emotionally involved with destinations (Barnes, 2002, Niemeyer, 2009). To quantify this emotional connection that individuals' make with destinations, researchers typically integrate attitudinal measures (typically quantified by using likert-scale based stated preferences of overall impression or level of attachment; see Yoon and Uysal, 2005) with behavioral measures such as visit frequency or amount of time spent (Alegre and Juaneda, 2006).

Still, destination attachment measures are unable to fully describe loyalty because they fail to distinguish relationships or loyalty by travel context (Petrick, 2005). For example, repeated visits to destination close to home might be interpreted as general loyalty, while an individual may only be "loyal" to that destination because of a limited time budget. In a travel context in which the individual had more time, s/he may have chosen a different destination. (This is the case of "spurious loyalty", see Kozak et al., 2002 and Petrick, 2005.) Research also suggests that, ultimately, individuals are generally not loyal to destinations per se, as much as they are loyal to the activities they are able to participate in at the destinations (see Shoemaker, 1994, Sung, 2004, Yoon and Uysal, 2005, Kemperman et al., 2006, Oom do Valle et al., 2008). Thus, it is important to evaluate the quality of a destination's activity opportunities, as well as 
individuals' interest in those activities within the travel context (as opposed to measuring loyalty based on attachment to a destination bereft of the activity opportunities at the destination and/or based on revisitation to the destination without consideration of the travel context).

\subsection{Loyalty through Activity Involvement}

Alternatively, loyalty through activity involvement assumes that individuals' leisure behavior is dictated by their psychological need to participate in various leisure activities, independent of the destinations in which they pursue them. Activity involvement theory, defined as "an unobservable state of motivation, arousal or interest toward a recreation activity or associated product" (Havitz and Dimanche, 1997), describes a process in which individuals participate in activities, become emotionally involved, and develop loyalties through established commitments (Gahwiler and Havitz, 1998, Josiam et al., 1999, Pritchard et al., 1999, Brey and Lehto, 2007). Loyalty measures for activity involvement are surprisingly similar to those collected to describe destination attachment, with behavioral measures (i.e. activity frequencies and patterns; see Brey and Lehto, 2007) and attitudinal measures (i.e. likert scales of 'resistance to change' and 'ability to choose'; see Pritchard et al., 1999).

The loyalty dimension through activity involvement is further explained through two important theories of behavior: recreation specialization and optimal arousal. Recreation specialization states that individuals become specialists in activities (as opposed to generalists) the more often they participate in the activities. In fact, specialization is a unique form of loyalty that is based exclusively on increased knowledge and skill sets rather than emotions (Devall, 1973; Bryan, 1977; Shibutani, 1955). Optimal arousal recognizes that individuals receive intrinsic benefits from participating in leisure activities. As a result, individuals are motivated to pursue those leisure activities that provide the highest personal benefits until they are satiated.

Activity involvement measures of loyalty provide insight into leisure behavior, but, like destination attachment measures, are unable to fully capture loyalty. First, the emphasis of activity involvement research remains on long-distance vacation activities, despite the continued recognition that daily intra-urban and long-distance inter-urban activities are inter-related in terms of the type and frequency of leisure activities pursued (Brey and Lehto, 2007, Larsen, 2008). In this context, the literature on intra-urban leisure activities and trips is especially sparse (Pozsgay and Bhat, 2001, Bhat and Gossen, 2004). Second, activity involvement theory also fails 
to differentiate activities by travel contexts. In fact, activity involvement theory explicitly assumes that leisure activities pursued locally and on long distance vacations are simply extensions of the same motivations. Brey and Lehto (2007) exemplify this assumption in their study comparing leisure activity commitment across daily and long-distance travel; they state that as individuals build experience with a daily version of an activity, they will participate in that activity wherever they go, because it is the same thing. While this may apply to skill-based leisure activities, it is also possible that people perceive leisure activities performed close to home as different from those that they pursue far away from home. In other words, rather than

optimal arousal necessarily only "kicking in" over time (so that individuals in a phase where they want to spend time in entertainment will travel both short distance and long distance for entertainment), optimal arousal may also operate continuously and may be implemented through the deliberate mechanism of changing travel context (so that individuals spend time in entertainment at a location close by to their home, but consciously avoid entertainment activities at a location farther away from their home). In addition, it is possible that individuals intrinsically have preference for certain activities, but only in combination with a certain travel context. For instance, social activities pursued locally (say, getting together with acquaintances) may hold little interest and loyalty for some individuals compared to regular family get-togethers pursued on long-distance trips.

\section{INCORPORATING THE TRAVEL CONTEXT}

To obtain a more thorough understanding of leisure activity loyalty and behavior, one must consider the travel context, which draws from both the destination satisfaction and the activity involvement theories. The process for developing loyalty to activities within a specific travel context can be described as (1) moving from involvement with an activity to (2) developing an attachment with that activity within a specific travel context to (3) building loyalty with that activity in that specific travel context. In such a conceptual process, the consideration of the travel context unifies the destination satisfaction and activity involvement aspects of loyalty in the following ways. First, travel context supports destination satisfaction because it is an integral part of destination image through place dependence (Moscardo et al., 1996, Chi and Qu, 2008, Yuksel et al., 2010). Second, travel context supports emotional destination attachment because it allows for individuals to "form activity attachments to types or contexts of travel" (Barnes, 2002, 
George and George, 2004). An example is the emotional attachment for family get-togethers at a particular family member's place that may entail long-distance travel. Third, travel context supports recreation specialization because as activities in one type of travel context become routine, individuals can develop loyalty to similar activities within a new travel context (Brey and Lehto, 2007). Finally, travel context supports optimal arousal because it allows for variety and novelty in leisure activities through deliberate choices of varying travel contexts at different destinations as well as considers activity involvement from a lifecycle perspective (Bargeman et al., 2002, Larsen, 2008). Ultimately, "a (leisure) trip cannot be regarded as independent from its travel context" (Schlich et al., 2004).

As a result, one needs to redefine loyalty measures based on the introduction of travel context to leisure activity loyalty. Three new types of leisure activity loyalties may be identified: general, independent, and dedicated. These new travel context-sensitive activity loyalties are identified by comparing individuals' participation in activities across specific travel contexts. For example, general activity loyalty describes when a household continually pursues a specific leisure activity, regardless of its travel context. Alternatively, independent activity loyalty refers to the case when a household continually pursues a specific leisure activity within a specific travel context, independent of their participation in that same activity in other travel contexts. Finally, dedicated activity loyalty represents the case when a household dedicatedly goes out of its way to continually pursue a specific leisure activity within a specific travel context, but is disinclined to participate in that specific activity type in other travel contexts. It is important to recognize that it is possible for households to demonstrate multiple types of loyalty across different types of leisure activities. For example, a household may be generally loyal to recreation and entertainment activities (meaning they tend to often hike and go to sporting events, both as part of intra-urban short-distance pursuits as well as on long-distance trips) as well as dedicatedly loyal to visiting daily travel (meaning they tend to regularly visit friends as part of their intra-urban leisure pursuits, but rarely do so on long distance trips). These new definitions of loyalty are further explored in a real-world empirical analysis that jointly examines the number of leisure activities individuals pursue across one dimension of travel context: travel extent (i.e. whether an individual participates in a leisure activity on a daily versus a longdistance basis). 


\section{DATA SOURCE}

The current study utilizes the 2001 National Household Travel Survey (NHTS). The survey, which was conducted between March 2001 and May 2002, is unique in that it recorded two sets of travel data from participating households from across the United States through a series of phone interviews and mailings (FHWA, 2004). The first set included all short distance daily travel and activities a household made over a 24 hour survey day; the second set included all long-distance (defined as travel to a destination 50 miles or further away from the home) travel and activities a household pursued over the 4 weeks (i.e. month) prior to the study day. Both sets of data included detailed trip, activity, and travel party information. Household sociodemographics, such as income, household composition, and home ownership were also collected.

\subsection{Sample Formation}

The sample used in this study was extracted from the NHTS data in a series of steps. First, the short distance daily travel and the long distance monthly travel datasets were formatted to determine the total number and types of out-of-home leisure activity episodes each household undertook during the 24 hour and 4-week survey periods, respectively. For short distance daily travel, households could record only one destination activity purpose for each trip. Five short distance leisure activity purposes were identified for the current analysis: entertainment (defined as "going out/ hanging out for entertainment, theater, sports event, going to bar, etc."), recreation (defined as "going to the gym, exercising, or playing sports"), resting (defined as "rest or relaxation"), sightseeing (defined as "visiting public place such as a historical site, museum, park, library, etc."), and visiting (defined as "visiting friends or relatives"). Each short distance trip with a leisure activity at the destination end of the trip was then translated as a single episode contribution to each activity purpose. Thus, a trip from home to a location involving recreation activity participation would contribute one recreation activity episode (though a trip back home from the recreation activity participation site to home would not contribute episodes to any leisure activity purpose). For each long-distance trip, households could record up to four activity purposes. Five long distance activity purposes, corresponding one-to-one with the groupings for short distance trips, were identified: entertainment (defined as "entertainment such as theater, concert, sports event, gambling, etc."), recreation (defined as "outdoor recreation such as sports, 
fishing, hunting, camping, boating, etc."), resting (defined as "rest or relaxation"), sightseeing (defined as such), and visiting (defined as "visiting friends or relatives"). Note that a longdistance trip with more than one activity purpose is recorded as contributing one episode to each activity purpose. Thus, if a household made a single long-distance trip during the 4 week period, and if this trip is pursued for both entertainment and recreation, we record this as one longdistance episode for entertainment and one long distance episode for recreation. This procedure was adopted because our emphasis is on leisure activity involvement. In any case, only $6.4 \%$ of the long-distance trips contained multiple activities and were therefore counted multiple times.

Once each leisure activity episode was identified by purpose, the number of short distance episodes per day and the number of long distance travel episodes per month were aggregated by activity purpose. Households that participated in no leisure activities and those that reported more than 15 short distance trips and/or 15 long distance leisure episodes during the recording period were removed. ${ }^{1}$ The resulting dataset comprised 28,294 households with at least one long-distance or daily leisure activity episode. The counts of short distance daily and long distance monthly leisure activity episodes (henceforth referred to as 'daily' episodes and 'long distance' episodes, respectively) were then merged with information collected regarding each household. Household data consists of location characteristics, economic information, and demographics. Further, information regarding the season of year and day of week of survey data collection was also available for each household.

Finally, to compare leisure activity loyalty across specific daily and long-distance activity purposes, the final dataset was partitioned into five comparison datasets, each focusing on the pair of daily and long distance episodes for a single activity purpose. In doing so, households were included in each specific comparison dataset only if they pursued at least one daily or one long distance leisure activity episode of that specific purpose. As a result, the entertainment, recreation, resting, sightseeing, and visiting datasets contained 7,106 households, 11,576 households, 2,264 households, 1,833 households, and 16,673 households, respectively.

\footnotetext{
${ }^{1}$ This upper limit was based on the observation that $99.9 \%$ of all households participated in 15 or fewer longdistance episodes and 15 or fewer daily trips. The remaining $0.1 \%$ of households reported an unrealistic number of trips.
} 


\subsection{Sample Description}

Of the 28,294 households in the full sample, $92.9 \%$ of households participated in at least one daily leisure episode and zero long distance leisure episodes, 3.4\% participated in zero daily leisure episodes and at least one long-distance episode, and 3.7\% participated in a combination of both daily and long distance episodes. The higher prevalence of daily episodes relative to long distance episodes in the mix of a typical household's leisure pursuits is to be expected, and illustrates the heavy influence of the travel context in leisure activity participation. The percentage of households participating in one or more episodes of each activity purpose within the daily travel context is provided in Table 1a, along with the average number of episodes of each activity purpose for households who participate in that activity purpose. Thus, the first row of Table 1a indicates that $20 \%$ of households participate in one or more entertainment episodes during the survey day and, among these households, the average number of entertainment episodes is 1.66 . The results from this table indicate that households are most likely to participate in one or more visiting episodes as part of their daily travel context, followed by recreation and entertainment. Daily resting and sightseeing are the leisure purposes most seldom participated in across the sampled households. Table $1 \mathrm{~b}$ provides the corresponding descriptive information for long distance travel. One notices the same trend across activity purposes as for daily leisure. However, it is also clear that visiting family and friends is a more dominant purpose category within long distance trips than it is for daily trips. In terms of the average number of episodes of participation in each activity purpose (among households who participate in that activity purpose), the second columns of Table $1 \mathrm{a}$ and $1 \mathrm{~b}$ show no substantial variations across activity purposes within each travel context, though visiting activity episodes are made more frequently than episodes of other leisure activity purposes in both the travel contexts.

The emphasis of the model analysis in the paper is on jointly modeling the number of daily and long distance episodes for each of the five leisure purposes identified in Table 1, and to examine which kind of travel context-based loyalty effect (general, independent, or dedicated) is appropriate for each of the five leisure purposes. 


\section{METHODOLOGY}

\subsection{Background}

In our empirical analysis, there are two dependent variables for each activity purpose - the number of daily leisure episodes and the number of long distance episodes. For each dependent variable, we use an ordered-response structure that assumes that there is an underlying continuous latent "loyalty" measure whose horizontal partitioning maps into the observed set of count outcomes. The higher the latent loyalty measure for daily leisure episodes, the higher is the observed number of daily leisure episodes. The same is true for long distance leisure episodes. Each of these daily leisure and long distance loyalty measures may be influenced by a multidimensional set of observed (to the analyst) household characteristics and unobserved (to the analyst) characteristics associated with the individual and her/his environment (such as lifestyle, health consciousness, sociability, etc.). However, the real comprehensive insight into leisure activity loyalty across travel contexts is obtained by comparing the direction of the effects of variables on the latent loyalty in the daily and long-distance contexts. For example, a variable that has the same sign of effect on both the daily and long distance (latent) loyalty measures contributes to general activity loyalty. A variable that has a significant impact on one loyalty measure, but not on the other contributes to independent activity loyalty. Finally, an exogenous variable that has opposite signs of effects on the two underlying loyalty variables contributes to dedicated activity loyalty. In addition, we recognize and accommodate the inter-relationship in the daily and long distance loyalty measures due to unobserved factors by jointly modeling the two loyalty measures. A positive dependence in the unobserved factors affecting the daily and long distance loyalty measures would imply general activity loyalty effects (due to the unobserved factors), zero dependence would imply independent activity loyalty, and negative dependence would mean dedicated travel loyalty. Of course, these effects may all vary by activity purpose, and hence the analysis of daily and long distance loyalties is undertaken separately by activity purpose.

\subsection{Model Structure}

In this section, we will present the model structure for a specific activity purpose. Thus, we suppress the index for activity purpose. For each household $q(q=1,2, \ldots, Q)$, let $f_{q}$ represents the number of daily leisure episodes and let $g_{q}$ represent the number of long distance leisure 
episodes. Let $m$ be an index for the number of daily leisure episodes $(m=0,1,2, \ldots, M)$ and let $n$ be the index for the number of (monthly) long distance episodes $(n=0,1,2, \ldots, N)$. The equation system takes the following form:

$$
\begin{aligned}
& f_{q}^{*}=\alpha^{\prime} x_{q}+v_{q}, f_{q}=m \text { if } \delta_{m-1}<f_{q}^{*}<\delta_{m} \\
& g_{q}^{*}=\beta^{\prime} y_{q}+\eta_{q}, g_{q}=n \text { if } \psi_{n-1}<g_{q}^{*}<\psi_{n}
\end{aligned}
$$

where $f_{q}^{*}$ and $g_{q}^{*}$ are the latent loyalty measures associated with daily and long distance activity episode participation; $x_{q}$ and $y_{q}$ are exogenous variable vectors (with no constant terms), including household location factors, household economic factors, household demographics, and season of year/day of week variables; $\alpha$ and $\beta$ are corresponding coefficient vectors to be estimated; $v_{q}$ and $\eta_{q}$ are random error terms; the $\delta_{m}$ and $\psi_{n}$ terms represent thresholds that relate the latent loyalty measures $f_{q}^{*}$ and $g_{q}^{*}$ to their observed counterparts $f_{q}$ and $g_{q}$, respectively, in the usual ordered-response fashion $\left(\delta_{-1}=-\infty, \delta_{M}=\infty ;-\infty<\delta_{0}<\delta_{1}<\delta_{2}<\ldots<\delta_{M-1}<\infty\right) \quad$ and $\left(\psi_{-1}=-\infty, \psi_{N}=\infty ;-\infty<\psi_{0}<\psi_{1}<\psi_{2}<\ldots<\psi_{N-1}<\infty\right)$. The error terms $v_{q}$ and $\eta_{q}$ may take any parametric distribution. In the current study, we examine both logistic and normal marginal distributions for these error terms, and choose the distribution that provides the best data fit. The error terms $v_{q}$ are assumed to be independent and identically distributed (IID) across individuals $q$, and the error terms $\eta_{q}$ are also assumed to be IID across individuals $q$. Further, for the logistic case, a standard logistic distribution is used for the error terms, while, for the normal case, a standard normal distribution is used for the error terms (these standardizations are innocuous normalizations needed for econometric identification). For presentation ease, let the marginal distribution of $v_{q}$ be $F($.$) and the marginal distribution of \eta_{q}$ be $G(.){ }^{2}$ Also, for notational convenience, define $b_{q m}=\delta_{m}-\alpha^{\prime} x_{q}$ and $d_{q n}=\psi_{n}-\beta^{\prime} y_{q}$.

With the preliminaries above, the probability that household $q$ undertakes $m$ daily episodes and $n$ long distance episodes can be written as follows:

\footnotetext{
${ }^{2}$ Thus, in the context of the current analysis, $F($.$) may be the standard logistic cumulative distribution function or$ the standard normal distribution function. The same is the case with $G($.$) . Note that, in the approach we use, it is not$ necessary that both $F($.$) and G($.$) should be simultaneously logistic (logistic-logistic) or simultaneously normal$ (normal-normal). Rather, we can also test the normal-logistic and logistic-normal pairings.
} 


$$
\begin{aligned}
& \operatorname{Pr}\left[f_{q}=m, g_{q}=n\right]=\operatorname{Pr}\left[b_{q, m-1}<v_{q}<b_{q m}, d_{q, n-1}<\eta_{q}<d_{q n}\right] \\
& =\operatorname{Pr}\left[v_{q}<b_{q m}, \eta_{q}<d_{q n}\right]-\operatorname{Pr}\left[v_{q}<b_{q m}, \eta_{q}<d_{q, n-1}\right] \\
& \quad-\left\{\operatorname{Pr}\left[v_{q}<b_{q, m-1}, \eta_{q}<d_{q n}\right]-\operatorname{Pr}\left[v_{q}<b_{q, m-1}, \eta_{q}<d_{q, n-1}\right]\right\}
\end{aligned}
$$

The above joint probability depends upon the dependence structure between the random variable $v_{q}$ and $\eta_{q}$. In the current paper, we use a flexible copula-based approach to characterize the dependence between these error terms. The copula approach allows the testing of several types of dependence structures, so that the analyst can choose the one that best fits the data rather than pre-imposing the very restrictive, but commonly used, bivariate normal (BVN) distribution assumption. More generally, let the joint cumulative distribution function of $v_{q}$ and $\eta_{q}$ be $H_{v, \eta}\left(z_{q 1}, z_{q 2}\right)$. Then, $H_{v, \eta}\left(z_{q 1}, z_{q 2}\right)$ can be expressed as a joint cumulative probability distribution of uniform $[0,1]$ marginal variables $U_{1}$ and $U_{2}$ as below:

$$
\begin{aligned}
H_{v, \eta}\left(z_{q 1}, z_{q 2}\right)= & \operatorname{Pr}\left[v_{q}<z_{q 1}, \eta<z_{q 2}\right]=\operatorname{Pr}\left[F^{-1}\left(U_{1}\right)<z_{q 1}, G^{-1}\left(U_{2}\right)<z_{q 2}\right] \\
& =\operatorname{Pr}\left[U_{1}<F\left(z_{q 1}\right), U_{2}<G\left(z_{q 2}\right)\right]
\end{aligned}
$$

Then, by Sklar's (1973) theorem, the above joint distribution (of uniform marginal variables) can be generated by a function $C_{\theta}(.,$.$) such that:$

$$
H_{v, \eta}\left(z_{q 1}, z_{q 2}\right)=C_{\theta}\left(u_{q 1}=F\left(z_{q 1}\right), u_{q 2}=G\left(z_{q 2}\right)\right)
$$

where $C_{\theta}(.,$.$) is a copula function and \theta$ is a dependency parameter (assumed to be scalar), together characterizing the dependency between $v_{q}$ and $\eta_{q}$.

The probability expression in Equation (2) can be re-written in terms of the copula function as:

$$
\begin{aligned}
\operatorname{Pr}\left[f_{q}=m, g_{q}=n\right]=C_{\theta} & {\left[F\left(b_{q m}\right), G\left(d_{q n}\right)\right]-C_{\theta}\left[\left(F\left(b_{q m}\right), G\left(d_{q, n-1}\right)\right]\right.} \\
& -\left\{C_{\theta}\left[\left(b_{q, m-1}\right), G\left(d_{q n}\right)\right]-C_{\theta}\left[F\left(b_{q, m-1}\right), G\left(d_{q, n-1}\right)\right]\right\}
\end{aligned}
$$

A variety of bivariate copula functions are available, and we test several of these for appropriateness in the current empirical context. These include the traditional Gaussian copula (i.e., the bivariate normal dependency structure), the Farlie-Gumbel-Morgenstern (FGM) copula, and the Archimedean class of copulas (including the Clayton, Gumbel, Frank, and Joe copulas). 
The reader is referred to Bhat and Eluru (2009) for a detailed discussion of these alternate copulas and the visual plots of their implied dependency. ${ }^{3}$

\subsection{Model Estimation}

The parameters to be estimated in the joint bivariate ordered response model include the $\alpha$ and $\beta$ vectors, the $M \delta_{k}$ parameters $\left(\delta_{-1}=-\infty, \delta_{M}=\infty ;-\infty<\delta_{0}<\delta_{1}<\delta_{2}<\ldots<\delta_{M-1}<\infty\right)$, the $N \psi_{n}$ parameters $\left(\psi_{-1}=-\infty, \psi_{N}=\infty ;-\infty<\psi_{0}<\psi_{1}<\psi_{2}<\ldots<\psi_{N-1}<\infty\right)$, and the $\theta$ parameter characterizing the dependency between the error terms for the copula under consideration. To write the log-likelihood function, define $I_{q}(m, n)$ as an indicator variable that takes the value of 1 if household $q$ pursues $m$ daily episodes and $n$ long distance episodes, and 0 otherwise. Then, the $\log$ likelihood function for the copula model takes the following form:

$\log L=\sum_{q=1}^{Q} \sum_{m=0}^{M} \sum_{n=0}^{N} I_{q}(m, n) \log \operatorname{Pr}\left[f_{q}=m, g_{q}=n\right]$

All the parameters in the model are estimated by maximizing the log-likelihood function above using the GAUSS matrix programming language.

\section{EMPIRICAL RESULTS}

\subsection{Variable Specification}

A variety of household characteristics were considered for each of the five leisure activity purposes. These household characteristics attempted to comprehensively capture both the behavioral and emotional loyalty push factors towards different activities. The specification included household location factors, household economic factors, household demographics, and season of year/day of week variables. Household location factors describe variation in households' activity loyalty across different metropolitan statistical areas, neighborhood types, and census regions. Household economic factors highlight differences in behavior based on home ownership, home type, income, telephone access, and vehicle ownership. Household

\footnotetext{
${ }^{3}$ An important note here. Many of the Archimedean copulas (including the Clayton, Gumbel, and Joe copulas) can only accommodate positive dependencies (unlike the FGM, Gaussian, and Frank copulas). Thus, these copulas cannot even handle the situation of potential negative dependence (i.e., dedicated travel loyalty effects). However, to examine the appropriateness of these copulas for the potential presence of dedicated loyalty effects, one only has to re-formulate the model system in Equation (1) by introducing the $v_{q}$ term in the first equation with a negative sign.
} 
demographics detail how activity loyalty varies by household members and lifecycle status. Finally, season of year and day of week identify the impact that alternative travel seasons, travel days, and September 11, 2001 has on leisure activity participation.

\subsection{Copula Specification and Dependency Effects}

For each activity purpose, the empirical analysis involved estimating models with two different univariate (i.e., marginal) distribution assumptions (normal and logistic) for the error terms $v_{q}$ and $\eta_{q}$, and seven different copula structures (independence, Gaussian, FGM, Clayton, Gumbel, Frank, and Joe). ${ }^{4}$ As discussed in Section 4, in the copula approach, there is no need to assume that the marginal distributions of the $v_{q}$ and $\eta_{q}$ error terms are simultaneously normal (normal-normal) or logistic (logistic-logistic); instead $v_{q}$ and $\eta_{q}$ terms can have a normallogistic or logistic-normal distribution. We examined all these four possible combinations for the error terms $v_{q}$ and $\eta_{q}$, as well as the seven copula dependency structures, for a total of 28 copula-based models for each activity purpose. In addition, we also estimated another batch of 12 copula-based models (four possible combinations of the error terms with three copula dependency structures after reversing the sign on the $v_{q}$ in the first equation to allow dedicated travel loyalty effects even with the Joe, Gumbel, and Clayton copulas). The Bayesian Information Criterion (BIC) is employed to select the best copula model, since the traditional likelihood ratio test for comparing the alternative copula-based models is not applicable (Bhat and Eluru, 2009). The BIC for a given copula model is equal to $-2 \ln (L)+K \ln (Q)$, where $\ln (L)$ is the log-likelihood value at convergence, $K$ is the number of parameters, and $Q$ is the number of observations. The copula that results in the lowest BIC value is the preferred copula. However, since all the competing models in the current analysis have the same exogenous variables and the same number of thresholds, the BIC information selection procedure measure is equivalent to selection based on the largest value of the log-likelihood function at convergence.

Among the different copula models tested for each of the five leisure activity purpose, the model that considers a normal marginal distribution for each of the error terms $v_{q}$ and $\eta_{q}$, and

\footnotetext{
${ }^{4}$ Due to space considerations, we are unable to provide additional details on the structures of different copula types. Interested readers are referred to Bhat and Eluru (2009). Also, note that the independence copula, as should be selfexplanatory, is a copula that assumes independence. In the notation of Section 5.2, the independence copula corresponds to $C_{\theta}\left(u_{1}, u_{2}\right)=u_{1} u_{2}$.
} 
uses a Frank copula to link the two error terms, consistently provided the best data fit. The Frank copula was much superior in particular to the Gaussian copula in the current empirical context for each activity purpose.

\subsection{Model Estimation Results}

The final estimation results for the entertainment, recreation, resting, sightseeing and visiting daily/long-distance activity copula models are detailed in Table 2 . The coefficients in the tables provide the effects of exogenous variables on the latent daily leisure loyalty and long distance leisure loyalty measures for each activity purpose. For each exogenous variable (all variables are dummy variables in the final specification), the base category is identified immediately after the variable label in the first column. A '-' entry in a cell of Table 2 indicates that the corresponding row exogenous variable also constitutes the base category when examining the influence of variables on the corresponding column activity purpose-travel context loyalty measure. The threshold values that translate the latent daily and long distance loyalty measures to the observed daily and long distance activity episodes are not shown in the table to conserve on space and because they do not have any substantive interpretation. The following discussion highlights some of the most interesting and meaningful results from the empirical estimations.

\subsubsection{Household Location Factors}

Household residential location significantly affects leisure activity loyalty. However, it is unclear whether this relationship is a result of leisure activity opportunities in the area of residence of a household, or self-selection effects where a household has already determined its leisure behavior and selects a residential location that supports the behavior. Either way, one of the significant loyalty parameters is the size of the metropolitan statistical area (MSA) a household lives in (relative to the smallest possible MSA, which has a population less than 250,000). The initial intuition is that the larger the MSA in which a household lives, the more leisure activities that should be available within a shorter distance of the household. However, the results indicate that, in general, and across all leisure activity purposes, households residing in larger MSAs have a higher long distance activity loyalty and lower daily activity loyalty than those residing in an MSA with a population less than 250,000. This is a case of dedicated activity loyalty toward long distance activities, perhaps triggered by a desire to "get-away" from busy 
stressful environments. Interestingly, households located outside of MSAs tend to form similar loyalties to long-distance leisure activities (relative to households residing in MSAs of a population less than 250,000) as those households located in large MSAs.

Another way to characterize household residential location is by neighborhood type, defined as rural, town, suburb/second city, or urban. Households located in rural regions show (relative to households in second cities or suburbs) a dedicated loyalty toward long-distance entertainment and recreation leisure activities (i.e., a higher propensity to participate in entertainment and recreation long distance and a lower tendency to participate in these activities close to home), and an independent loyalty toward long-distance sightseeing leisure activities (i.e., a higher propensity to participate in sightseeing activities long distance with no inclination one way or the other with respect to sightseeing activities close to home). Households located in towns also tend to demonstrate a dedicated loyalty toward long-distance entertainment and sightseeing leisure activities. This is intuitive, as there are traditionally fewer entertainment, sightseeing or recreation activity opportunities available in local rural areas and smaller towns. Households located in urban regions, however, tend to demonstrate an independent disloyalty towards long-distance entertainment and visiting leisure activities. Note that this does not imply that urban households participate more in daily entertainment or visiting activities than nonurban household; rather, urban households show a strong disinterest in traveling long distances to pursue these types of activities, relative to non-urban households.

\subsubsection{Household Economic Factors}

It is widely recognized that home ownership has a number of social and psychological benefits, including higher social status, higher rates of social interaction, and more neighborhood/ community involvement due to the financial investment (Rohe and Basolo, 1997; Dupuis and Thorns, 1998). Renters similarly report high levels of social interaction, supported by their flexible discretionary incomes/ time rather than their personal or financial commitments to an area (Mulder, 2006; McWhinney, 2010). It is interesting, however, that despite their motivations for pursuing leisure activities these households demonstrate nearly identical patterns of leisure activity loyalty. For example, the results highlight similar dedicated loyalties towards daily visiting leisure activities and independent disloyalties towards daily entertainment leisure activities. This would seem to further support the idea that leisure activities are (a) highly related 
to social interactions and (b) a fixed component of households' lives regardless of their social status or discretionary income.

Annual household income is another common economic/lifestyle factor associated with leisure travel. Households with higher incomes can afford to travel further, more often, and for longer periods of time. The model estimation compared leisure activity loyalty across four income levels, relative to those less than $\$ 20,000$. Interestingly, households in each of the higher income levels, in general, show independent and dedicated long distance loyalty across all activity purposes. This supports the belief that most households consider long-distance leisure travel, such as vacations, a normal (and expected) part of their lives. However, families with the lowest level of income are not able to afford this kind of long distance leisure travel.

Car ownership is often recognized as an extension of income, with a range of results (Macintyre et al., 1998; Pucher and Renne, 2003). For low income households, owning more vehicles limits discretionary funds that could be used for leisure travel (Mallet and McGuckin, 2000). For medium and higher incomes, however, these discretionary funds are not a concern, and additional vehicles allow these households to pursue significantly more long-distance recreation/vacation trips (Georggi and Pendyala, 2001; Guiliano and Dargay, 2006). The estimation results highlight these differences when combined with the income variables. The more cars low-income households own, the stronger the dedicated loyalty they demonstrate towards long-distance leisure activities. Clearly these households save their limited discretionary funds for long-distance vacation travel, rather than day to day recreation. Alternatively, owning additional cars shifts high-income households to independent loyalty of long-distance recreation leisure activities. This means that these high-income households enjoy long-distance recreation, but they are not limited by any means for pursuing it occasionally on a daily basis.

Finally, the widespread use of cell phones has dramatically altered the way households organize activities and schedule travel. Households with more cell phones demonstrate a blending of work and leisure activities, making it possible to pursue more leisure activities, allocate more time for each leisure activity, and incorporate longer leisure trips into their daily schedules (Leung and Wei, 2000; Palen et al,, 2001; Bhat et al., 2004; Srinivasan and Raghavender, 2006). A further benefit of this blending is the ability to coordinate complicated family logistics and keep in contact with a wide extended social/familial network (Prasopoulou et al., 2006; Gilleard et al., 2007). The estimation results support these observations, showing 
that households with more cell phones use their flexible time to develop strong loyalties towards long-distance leisure activities. Specifically, these households demonstrate a dedicated loyalty towards long-distance recreation and visiting leisure activities as well as an independent loyalty towards long-distance entertainment and sightseeing leisure activities. Even more notable, households with more cell phones demonstrate an independent disloyalty towards daily resting leisure activities, meaning that they'd rather spend their daily leisure time on other activities.

\subsubsection{Household Demographics}

It is commonly recognized within the current literature that as households evolve over time, their travel patterns change as well. This study identified a variety of household demographics and lifecycle factors that affect leisure activity loyalties, the first set of which is the number of different types of household members. Households with more adults, or perhaps exclusively adults, demonstrate an independent loyalty towards daily entertainment, recreation, and visiting leisure activities. While the loyalty to adult-oriented activities is not surprising, the loyalty to daily travel contexts is. It most likely draws attention to the difficulty that households have in planning or taking long-distance trips around multiple adults' schedules and responsibilities. Interestingly, households with more children demonstrate a similar loyalty to the daily travel context, perhaps because it is hard to plan and manage long distance trips with more children. Households with more drivers, on the other hand, demonstrate an independent loyalty towards long-distance entertainment and visiting leisure activities. Clearly, household members who have the ability to travel long-distance take advantage of this opportunity. However, as household members take on work responsibilities, the household's ability to participate in leisure appears to decrease, especially in recreation-oriented leisure (regardless of travel context).

One of the most significant household characteristics affecting leisure travel is the presence (and ages) of children. While most household leisure activities are ultimately decided upon by the parents, children have been known to influence parents' decisions. Overall households with children are extremely loyal to the daily travel context, which is consistent with much of the literature. It is much easier for parents as well as children to pursue local leisure activities, due to limited free time and the difficulty in planning and managing long trips. Additionally, children tend to prefer routines and familiarity with destinations, which further supports local travel contexts (Wildenger et al., 2008). This is especially seen in households 
with children aged 0 to 5 years, who show an independent loyalty to all types of daily leisure activities. Households with young children may not have a considerable amount of free time, but these new parents appear to use their time to expose young children to all types of leisure activities. The variety of leisure activities may serve as a distraction for young children and a break for parents. As children get older, they develop their own preferences and may start to define routines. The results indicate that households with children aged 6-21 show a dedicated loyalty towards daily visiting activities (i.e., a higher propensity to participate in daily visiting pursuits, with a corresponding disinclination to participate in long distance visiting pursuits).

The variables related to the age of the household head suggest loyalty evolution trends over time. In general, households tend to exhibit less loyalty toward daily entertainment and visiting activities. When taken together, the effects of the "children" variables and the "age of household head" variables suggest that when children leave home, the "empty nester" households participate less in daily leisure activities, especially entertainment and visiting. The authors acknowledge that the data (like any cross-sectional data) does not fully distinguish between changes in cohort (or life-course) effects from generational effects, and it would be useful to further explore how loyalty differs across these.

\subsubsection{Season of Year/ Day of Week Variables}

The final model characteristics consider the travel period in which each household pursued their leisure activities. The estimation results confirm that distinct seasonal leisure activity loyalties are formed during the year, due to changes in weather, holidays, and work/school commitments. In the fall, households demonstrate a dedicated loyalty towards daily entertainment leisure activities, which include group leisure activities such as sporting events, going out with friends, or general "hanging out". Traditionally, this is the season when schools start, group activities begin, and households reconnect with their social groups; which inherently tends to lead to an increase in the number of these group leisure activities. A few months later, during winter, households demonstrate an independent loyalty towards long-distance visiting leisure activities. As one would expect, the holidays during winter encourage households to make long-distance trips they make to visit family and friends that they may not see regularly. Households surveyed in the spring tend to demonstrate a dedicated loyalty towards daily sightseeing and long-distance visiting leisure activities. These findings indicate that as the weather gets warmer, households 
become loyal to spending time outside both at home and with friends and family further away. Across each season, households demonstrate an independent disloyalty towards daily recreation and resting leisure activities, relative to summer.

One would additionally anticipate differences in leisure loyalty depending on the day of the week. Of course, this variable is not relevant for long distance episodes, because long distance episodes were based on a 4-week reporting period. But, for daily travel, the results show higher participation loyalty (or propensity) over the weekends relative to weekdays, a clear manifestation of more time availability to pursue leisure over the weekends.

Since half of the survey was completed before September 11, 2001, we considered the impact the terrorist attack had on leisure activity loyalties, to obtain a general sense of the effects of national-level incidents on leisure activity loyalties. After the attack, households demonstrated a general disloyalty toward recreation leisure activities regardless of whether it was daily or long-distance. This is consistent with the overall reduction in recreational travel during that time. Households also demonstrated an independent disloyalty toward long-distance visiting leisure activities. This is to be expected as visiting is the most common leisure activity and would naturally face the biggest decline in associated travel after an extreme event. The increased dedicated loyalty toward long-distance entertainment and resting leisure activities in the immediate aftermath of $9 / 11$ is interesting, and needs more careful investigation in future studies.

\subsubsection{Dependency Parameters}

In our empirical analysis, the dependency parameter in the Frank copula consistently turned out to be negative and highly significantly different from zero for each activity purpose (see bottom row of Table 2). ${ }^{5}$ The implication is that unobserved factors that increase the daily loyalty measure reduce the long distance loyalty measure, and vice versa. This supports the notion that, after controlling for observed factors, households choose different kinds of activity purposes in their daily leisure and their long distance leisure pursuits. This is a case of dedicated travel loyalty effects due to unobserved factors. The magnitude of the negative relationship due to

\footnotetext{
${ }^{5}$ The Frank's copula allows a stronger central clustering of data points and lesser clustering at the edges relative to the Gaussian copula. In the current empirical context, this means that individuals are likely to be clustered around the medium-medium levels of the two-dimensional daily and long distance loyalty spectrum, and less so at the lowhigh end or the high-low end of the spectrum, given the negative dependence.
} 
unobserved factors in the daily and long distance loyalty measures for each activity purpose can be assessed using the Kendall's measure of dependency. ${ }^{6}$ The dependency values for each of the five activity purposes are: -0.63 (entertainment), -0.50 (recreation), -0.73 (resting), -0.76 (sightseeing), and -0.48 (visiting). Clearly, the highest level of loyalty dissonance between the daily and long distance travel contexts is for sightseeing and resting activities.

\section{CONCLUSIONS}

Leisure activities, and their associated trips, account for a significant percentage of US households' annual travel. Unfortunately, due to the variety and flexibility of these activities, leisure travel behavior is still not well understood. Despite the irregular nature of these activities, individuals still develop leisure preferences, routines and habits over extended periods of time, similar to non-leisure travel behavior. As a result, researchers have begun to recognize the importance of considering activity loyalty when discussing leisure travel behavior. However, the field lacks a clear, unified conceptual understanding of leisure loyalty, and has seen only limited empirical analyses of leisure loyalty behavior. Perhaps even more importantly, there is inadequate consideration of the travel context (i.e. the situational conditions associated with individuals' travel decisions and activity participation) in existing leisure loyalty research.

The goal of this paper is to contribute to our understanding of leisure activity participation by considering leisure activity loyalty within a travel context. To our knowledge, this is the first study to explicitly do so. Specifically, the study focuses on one dimension of travel context: travel extent (i.e. whether an individual participates in a leisure activity on a daily versus a long-distance basis). As such, this paper develops a unified conceptual framework for considering leisure activity loyalties within a travel context based on two distinct elements of leisure loyalty behavior - destination satisfaction and activity involvement. The framework is based on the notion that individuals' leisure activity involvement has become situational, heightened by specific travel context instances or circumstances. As a result, three new types of loyalty measures were introduced that incorporate travel context: general, independent, and

\footnotetext{
${ }^{6}$ Kendall's measure of dependency $(\tau)$ transforms the dependency parameter $(\theta)$ into a number between -1 and 1 (see Bhat and Eluru, 2009). For the Frank copula, $\tau=1-\frac{4}{\theta}\left[1-\frac{1}{\theta} \int_{t=0}^{\theta} \frac{t}{e^{t}-1} d t\right]$ and $-1<\tau<1$. Independence is attained in Frank's copula as $\theta \rightarrow 0$.
} 
dedicated. These new travel context-sensitive activity loyalties were then measured for five distinct leisure activities using a unique 2001 NHTS dataset comprised of households' daily and long-distance leisure activities within a new copula-based model methodology that incorporated an underlying latent loyalty measure. The empirical analysis evaluated the impact of household location factors, household economic factors, household demographics, and season of year/day of week variables on these leisure activity loyalties.

The empirical findings confirmed that households strongly associate leisure activities with travel contexts, and, as a result, their loyalty to leisure activities is closely tied to the travel context in which they are pursued. In fact, most of the activity loyalties identified in this study were heavily skewed towards either daily or long distance travel (as noted by the abundance of independent and dedicated activity loyalties as well as the highly negative dependency parameters). There were very few general activity loyalties that describe households' pursuit of leisure activities independent of travel context. The specific scale and type of leisure activity loyalties households demonstrated, however, varied greatly by their specific needs and interests. Not surprisingly, households' loyalties to activities and travel contexts were shown to shift over time, based on household members' ages, the presence of children, current home location, and even season of the year. Clearly travel contexts, and specifically travel extents, need to be considered when studying or planning for leisure activities.

The results also provide insight into how households differentiate long distance and daily travel extents. It would seem that many of the loyalties that households have for long distance activities are rooted in their inherent enjoyment of travel, their need to access extended social networks, and their interest in simply getting-away. Many types of households pair visiting, entertainment and recreation activities with long distance travel to take advantage of these travel extent characteristics. For example, households in urbanized areas have access to a variety of nearby activity opportunities, but they instead develop loyalties to all types of leisure activities farther away. Alternatively, many of the loyalties that households have for daily activities are rooted in their affinity for convenience and the minimal planning required. For example, households with more adults and children tend to overwhelmingly develop loyalties to all types of daily activities, perhaps to accommodate leisure activities within their complex schedules. Ultimately, this study of loyalty highlights that households do not develop attachments to 
activities without considering travel extent. Rather, travel extents form a significant component of activity experiences and can even be meaningful experiences in-and-of themselves.

With so many individual and household factors being controlled for in the model, these empirical results can be generalized for wider audiences across the country. The results are also reliable, as the copula-based methodology is both conceptually and mathematically sound. Of course, it should be recognized that there are still some factors influencing leisure travel behavior, such as household life cycle type and traveler perceptions/preferences, that were not collected as part of the NHTS survey but would provide additional insights. Still, this paper attempts to capture these factors through the use of car, cell phone, and home ownership variables, similar to the use in previous literature, but surely more detailed analyses of these surrogate factors is recommended to improve generalizability. Additionally, social networks play a significant role in defining travel contexts, especially those for leisure travel, and it would naturally improve the generalization of travel context research by incorporating social networks as well. Furthermore, this study focuses on one broad type of travel context, and, as such, the results cannot be directly transferred to describe other travel contexts.

Redefining leisure activity loyalty within a travel context has significant application, conceptual, and methodological implications for travel planning, demand modeling, and tourism management. Planners have traditionally used destination loyalty to identify and market towards specific population groups. Travelers who are loyal to specific leisure activities or destinations are significantly more likely to select destinations in which they can participate in those activities during their "free time". Additionally, these loyal individuals are much less sensitive to changes in costs and policies associated with those leisure activities. By identifying the activity loyalties of travelers, city and tourism planners will be able to develop destination activities and adopt appropriate policies and price-points to effectively retain current visitors as well as attract new visitors. Developing loyalty improves economic strength, through reduced price sensitivities and expanded customer retention/attraction, as well as improves transportation planning models, through better estimates of travel behavior. However, previous definitions of loyalty have not been very successful, because of their inability to account for individuals' travel contexts. The study results indicate that, through independent and dedicated activity loyalty, individuals are generally not loyal to destinations per se, as much as they are loyal to the activities they are able to participate in at the destinations in a certain travel context. Thus, it is important to evaluate 
the quality of a destination's activity opportunities, as well as individuals' interest in those activities and the travel context to the destination (as opposed to measuring loyalty based on attachment to a destination bereft of the activity opportunities at the destination and/or based on revisitation to the destination without consideration of the travel context). This improved conceptualization of leisure activity behavior can improve methodologies for predicting and planning for individuals' travel patterns. For example, one possible improvement to activitybased models would be to first model each individuals' level of leisure activity loyalty (either in terms of a latent scale-value or level of typical daily and monthly participation), and then use this value as an independent variable to predict travel decisions and other behaviors.

There are, of course, many opportunities to extend the current study. First, the study exclusively considered leisure activities. However, many leisure activities are undertaken in conjunction with work-related activities, so it is important to further study the impact that these two types of activities have on each other. Second, this study modeled each leisure activity purpose independently. But, households are constantly prioritizing among all leisure activities when they make decisions, so it is important to further study the interactions between different activity purpose loyalties. Considering individuals' preferences over all activities would provide insights into activity substitutions, combinations, and exclusivity. Third, this study considered only a single day for short trips and a month for long trips. However, households pursue leisure activities throughout the year, so it is important to further study how these loyalties evolve for a household over a year, multiple years, or (at least) over different seasons. Finally, this study treated households as the decision-making unit. However, each household is composed of a variety of members, and studying how the activity loyalties of individual members are shared, reinforced, and compromised within the family unit would be an interesting avenue for further research.

\section{ACKNOWLEDGEMENTS}

The authors acknowledge the helpful comments of three anonymous reviewers on an earlier version of the paper. This research was partially funded by a Southwest Region University Transportation Center grant. The authors are grateful to Lisa Macias for her help in formatting this document. 


\section{REFERENCES}

Alegre J, Juaneda C (2006) Destination loyalty: consumers' economic behavior. Annals of Tourism Research 33(3): 684-706.

Bandyopadhyay S, Martell M (2007) Does attitudinal loyalty influence behavioral loyalty? A theoretical and empirical study. Journal of Retailing and Consumer Services 14(1): 3544.

Bargeman B, Joh C-H, Timmermans H (2002) Vacation behavior using a sequence alignment method. Annals of Tourism Research 29(2): 320-337.

Bargeman B, van der Poel H (2006) The role of routines in the vacation decision-making process of Dutch vacationers. Tourism Management 27(4): 707-720.

Barnes J (2002) From the customer's perspective: defining loyalty. Bristol Group, Inc.

Bhat CR, Sivakumar A, Axhausen KW (2004) An analysis of the impact of information and communication technologies on non-maintenance shopping activities. Transportation Research Part B 38(1): 39-60.

Bhat CR, Eluru N (2009) A copula-based approach to accommodate residential self-selection effects in travel behavior modeling. Transportation Research Part B 43(7): 749-765.

Bhat CR, Gossen R (2004) A mixed multinomial logit model analysis of weekend recreation episode type choice. Transportation Research Part B 38(9): 767-787.

Brey ET, Lehto XY (2007) The relationship between daily and vacation activities. Annals of Tourism Research 34(1): 160-180.

Bryan H (1977) Leisure value systems and recreational specialization: the case of trout fisherman. Journal of Leisure Research 9: 74-187.

Castro CB, Armario EM, Ruiz DM (2007) The influence of market heterogeneity on the relationship between a destination's image and tourists' future behaviour. Tourism Management 28(1): 175-187.

Chi CG, Qu H (2008) Examining the structural relationships of destination image, tourist satisfaction and destination loyalty: an integrated approach. Tourism Management 29(4): 624-636.

Devall B (1973) The development of leisure social worlds. Humboldt Journal of Social Relations 1: 53-59.

Dupius A, Thorns DC (1998) Home, home ownership and the search for ontological security. The Sociological Review 46(1): 24-47.

Federal Highway Association (FHWA) (2004) 2001 National household travel survey: user's guide. January 2004: Version 3.

Gahwiler P, Havitz ME (1998) Toward a relational understanding of leisure social worlds, involvement, psychological commitment, and behavioral loyalty. Leisure Sciences 20(1): $1-23$.

George BP, George BP (2004) Past visits and the intention to revisit a destination: places attachment as the mediator and novelty seeking as the moderator. Journal of Tourism Studies 15(2): 51-66.

Georggi NL, Pendyala RM (2001) Analysis of long-distance travel Behavior of the elderly and low income. Conference Proceedings, Personal Travel: The Long and Short of It. Transportation Research Circular, E-C026.

Gilleard C, Hyde M, Higgs P (2007) Community and communication in the third age: the impact of internet and cell phone use on attachment to place in later life in England. Journal of Gerontology: Social Sciences 63(4): S276-S283. 
Guiliano G, Dargay J (2006) Car ownership, travel and land use: a comparison of the US and Great Britain. Transportation Research Part A 40: 106-124.

Havitz ME, Dimanche F (1997) Leisure involvement revisited: conceptual conundrums and measurement advances. Journal of Leisure Research 29(3): 245-278.

Hernandez-Lobato L, Solis-Radilla MM, Moliner-Tena MA, Sanchez-Garcia J (2006) Tourism destination image, satisfaction and loyalty: a study in Ixtapa-Zihuatanejo, Mexico. Tourism Geographies 8(4): 343-358.

Holecek D, White R (2007) Record-high gas prices won't negatively affect travelers, MSU researcher says. Michigan State University Tourism Center News Release: May 17, 2007.

Jacoby J, Kyner DB (1973) Brand loyalty versus repeat purchasing behavior. Journal of Marketing Research 10(1): 1-9.

Josiam BM, Smeaton G, Clements CJ (1999) Involvement: travel motivation and destination selection. Journal of Vacation Marketing 5(2): 167-175.

Kemperman ADAM, Ponje MMW, Timmermans HJP (2006) Analyzing heterogeneity and substitution in trip making propensity to urban parks: a mixed logit model. Tourism Analysis 10: 223-232.

Kozak M, Huan TC, Beaman J (2002) A systematic approach to non-repeat and repeat travel: with measurement and destination loyalty concept implications. Journal of Travel and Tourism Marketing 12(4): 19-38.

Lam T, Hsu CHC (2006) Predicting behavioral intention of choosing a travel destination. Tourism Management 27(4): 589-599.

Larsen J (2008) De-exoticizing leisure travel. Leisure Studies 27(1): 21-34.

Lee J, Graefe AR, Burns RC (2007) Examining the antecedents of destination loyalty in a forest setting. Leisure Sciences 29(5): 463-481.

Leung L, Wei R (2000) More than just talk on the move: uses and gratifications of the cellular phone. Journalism and Mass Communication Quarterly 77(2): 308-320.

Limtanakool N, Dijst M, Schwanen T (2006) Long-distance travel: a decomposition analysis for the UK and the Netherlands. Tijdschrift voor Economische en Sociale Geografie 97(4): 389-404.

Lockwood A, Srinivasan S, Bhat CR (2005) An exploratory analysis of weekend activity patterns in the San Francisco Bay area. Transportation Research Record 1926: 70-78.

Macintyre S, Ellaway A, Der G, Ford G, Hunt K (1998) Do housing tenure and car access predict health because they are simply markers of income or self esteem? A Scottish study. Journal of Epidemiology \& Community Health 52: 657-664.

Mallet WJ, McGuckin N (2000) Driving to distractions: recreational trips in private vehicles. Transportation Research Record 1719: 267-272.

McMullan R, Gilmore A (2008) Customer loyalty: an empirical study. European Journal of Marketing 42(9/10): 1084-1094.

McWhinney JE (2010) To rent or buy? There's more to it than money. Investopedia, Article 011305.

Moscardo G, Morrison AM, Pearce PL, Lang C, O’Leary JT (1996) Understanding vacation destination choice through travel motivation and activities. Journal of Vacation Marketing 2(2): 109-122.

Mulder CH (2006) Home-ownership and family formation. Journal of Housing and the Built Environment. 21: 281-298. 
Niemeyer P (2009) Going beyond behavioral loyalty. Return on Behavior Magazine. http:/www.returnonbehaviormagazine.com/main-articles/going-beyond-behavioralloyalty-6.html

Oom do Valle P, Correia A, Rebelo E (2008) Determinants of tourism return behavior. Tourism and Hospitality Research 8(3): 205-219.

Palen L, Salzman M, Youngs E (2001) Discovery and integration of mobile communications in everyday life. Personal and Ubiquitous Computing 5: 109-122.

Petrick JF (2005) Reoperationalising the loyalty framework. Tourism and Hospitality Research 5(3): 199-212.

Pozsgay MA, Bhat CR (2001) Destination choice modeling for home-based recreational trips. Transportation Research Record 1777: 47-54.

Prasopoulou E, Pouloudi A, Panteli N (2006) Enacting new temporal boundaries: the role of mobile phones. European Journal of Information Systems 15: 277-284.

Pritchard MP, Havitz ME, Howard DR (1999) Analyzing the commitment-loyalty link in service contexts. Journal of the Academy of Marketing Science 27(3): 333-348.

Pucher J, Renne JL (2003) Socioeconomics of urban travel: evidence from the 2001 NHTS. Transportation Quarterly 57(3): 49-77.

Rohe WM, Basolo V (1997) Long-term effects of home ownership on the self-perceptions and social interactions of low-income persons. Environment and Behavior 19(6): 793-819.

Schlich R, Schonfelder S, Hanson S, Axhausen KW (2004) Structures of leisure travel: temporal and spatial variability. Transport Reviews 24(2): 219-237.

Shibutani T (1955) Reference groups as perspectives. The American Journal of Sociology 60(6): $562-569$.

Shoemaker S (1994) Segmenting the US travel market according to benefits realized. Journal of Travel Research 32(3): 8-21.

Shoemaker S, Lewis RC (1999) Customer loyalty: the future of hospitality marketing. International Journal of Hospitality Management 18(4): 345-370.

Sklar A (1973) Random variables, joint distribution functions, and copulas. Kybernetika 9: 449460.

Srinivasan KK, Raghavender PN (2006) Impact of mobile phones on travel: empirical analysis of activity chaining, ridesharing and virtual shopping. Transportation Research Record 1977: 258-267.

Sung HH (2004) Classification of adventure travelers: behavior, decision making, and target markets. Journal of Travel Research 42(4): 343-356.

US Travel Association (2005) US travel market overview - travel volumes \& trends.

US Travel Association (2008) Annual travel forecast.

Wildenger LK, McIntyre LL, Fiese BH, Eckert TL (2008) Children's daily routines during kindergarten transition. Early Childhood Education Journal 36(1): 69-74.

Yoon Y, Uysal M (2005) An examination of the effects of motivation and satisfaction on destination loyalty: a structural model. Tourism Management 26(1): 45-56.

Yuksel A, Yuksel F, Bilim Y (2010) Destination attachment: effects on customer satisfaction and cognitive, affective and conative loyalty. Tourism Management 31(2): 274-284. 


\section{LIST OF TABLES}

Table 1: Descriptive Statistics of Participation by Leisure Purpose and Travel Context

Table 1a: Daily Leisure Activity Loyalty

Table 1b: Long-Distance Leisure Activity Loyalty

Table 2: Leisure Activity Models Results 
Table 1: Descriptive Statistics of Participation by Leisure Purpose and Travel Context

Table 1a: Daily Leisure Activity Loyalty

\begin{tabular}{|c|c|c|}
\hline Daily Leisure Activity Purpose & $\begin{array}{c}\text { Total Number (\%) of Households } \\
\text { Participating In This Type of Daily } \\
\text { Leisure Activity }\end{array}$ & $\begin{array}{c}\text { Average Number of Activity } \\
\text { Episodes of Households } \\
\text { Participating in This Type of Daily } \\
\text { Leisure Activity }\end{array}$ \\
\hline Entertainment & $5666(20.0 \%)$ & 1.66 \\
Recreation & $10793(38.1 \%)$ & 1.59 \\
Resting & $1497(5.3 \%)$ & 1.65 \\
Sightseeing & $1246(4.4 \%)$ & 1.62 \\
Visiting & $12915(45.6 \%)$ & 1.85 \\
\hline
\end{tabular}

Table 1b: Long-Distance Leisure Activity Loyalty

\begin{tabular}{|c|c|c|}
\hline $\begin{array}{c}\text { Long-Distance Leisure Activity } \\
\text { Purpose }\end{array}$ & $\begin{array}{c}\text { Total Number (\%) of Households } \\
\text { Participating In This Type of Long- } \\
\text { distance Leisure Activity }\end{array}$ & $\begin{array}{c}\text { Average Number of Activity } \\
\text { Episodes of Households } \\
\text { Participating in This Type of Long- } \\
\text { distance Leisure Activity }\end{array}$ \\
\hline Entertainment & $1734(6.1 \%)$ & 2.10 \\
Recreation & $1191(4.2 \%)$ & 2.05 \\
Resting & $811(2.9 \%)$ & 2.02 \\
Sightseeing & $618(2.2 \%)$ & 1.83 \\
\hline
\end{tabular}


Table 2: Leisure Activity Models Results

\begin{tabular}{|c|c|c|c|c|c|c|c|c|c|c|c|c|c|c|c|c|c|c|c|c|}
\hline \multirow[b]{4}{*}{ Household Location Factors } & \multicolumn{4}{|c|}{ Entertainment } & \multicolumn{4}{|c|}{ Recreation } & \multicolumn{4}{|c|}{ Resting } & \multicolumn{4}{|c|}{ Sightseeing } & \multicolumn{4}{|c|}{ Visiting } \\
\hline & \multicolumn{2}{|c|}{$\begin{array}{c}\text { Daily Short } \\
\text { Distance } \\
\text { Loyalty } \\
\end{array}$} & \multicolumn{2}{|c|}{$\begin{array}{c}\text { Monthly Long } \\
\text { Distance } \\
\text { Activities } \\
\end{array}$} & \multicolumn{2}{|c|}{$\begin{array}{c}\text { Daily Short } \\
\text { Distance } \\
\text { Loyalty } \\
\end{array}$} & \multicolumn{2}{|c|}{$\begin{array}{c}\text { Monthly Long } \\
\text { Distance } \\
\text { Activities }\end{array}$} & \multicolumn{2}{|c|}{$\begin{array}{c}\text { Daily Short } \\
\text { Distance } \\
\text { Loyalty } \\
\end{array}$} & \multicolumn{2}{|c|}{$\begin{array}{c}\text { Monthly Long } \\
\text { Distance } \\
\text { Activities }\end{array}$} & \multicolumn{2}{|c|}{$\begin{array}{c}\text { Daily Short } \\
\text { Distance } \\
\text { Loyalty } \\
\end{array}$} & \multicolumn{2}{|c|}{$\begin{array}{c}\text { Monthly Long } \\
\text { Distance } \\
\text { Activities } \\
\end{array}$} & \multicolumn{2}{|c|}{$\begin{array}{c}\text { Daily Short } \\
\text { Distance } \\
\text { Loyalty } \\
\end{array}$} & \multicolumn{2}{|c|}{$\begin{array}{c}\text { Monthly Long } \\
\text { Distance } \\
\text { Activities } \\
\end{array}$} \\
\hline & Coeff & t-stat & Coeff & t-stat & Coeff & t-stat & Coeff & t-stat & Coeff & t-stat & Coeff & t-stat & Coeff & t-stat & Coeff & t-stat & Coeff & t-stat & Coeff & t-stat \\
\hline & & & & & & & & & & & & & & & & & & & & \\
\hline $\begin{array}{l}\text { MSA Population } \\
\text { (Base: ...less than 250,000) }\end{array}$ & & & & & & & & & & & & & & & & & & & & \\
\hline ...between $250,000 \& 499,999$ & - & - & 0.077 & 1.14 & 0.078 & 2.25 & - & - & - & - & - & - & - & - & - & - & - & - & 0.057 & 1.42 \\
\hline ...between $500,000 \& 999,999$ & -0.299 & -5.74 & 0.406 & 5.42 & - & - & 0.235 & 3.51 & -0.135 & -1.45 & 0.192 & 1.69 & - & - & - & - & -0.186 & -5.54 & 0.386 & 8.63 \\
\hline $\begin{array}{l}\text {...between } 1,000,000 \& \\
2,999,999\end{array}$ & -0.240 & -6.01 & 0.373 & 5.88 & -0.106 & -3.25 & 0.384 & 7.29 & -0.241 & 3.53 & 0.366 & 4.44 & -0.241 & -2.96 & 0.223 & 2.33 & -0.247 & -9.50 & 0.523 & 14.49 \\
\hline$\ldots$ over $3,000,000$ & -0.230 & -5.95 & 0.385 & 6.48 & -0.129 & -4.16 & 0.385 & 7.79 & -0.289 & -4.89 & 0.379 & 5.13 & -0.245 & -3.58 & 0.249 & 3.22 & -0.274 & -10.90 & 0.527 & 14.76 \\
\hline ...outside of an MSA & -0.305 & -7.69 & 0.507 & 8.44 & -0.048 & -1.42 & 0.261 & 4.55 & - & - & 0.105 & 1.28 & -0.238 & -3.12 & 0.302 & 3.37 & -0.211 & -8.88 & 0.555 & 16.51 \\
\hline $\begin{array}{l}\text { City Size } \\
\text { (Base: ...in Second City or } \\
\quad \text { Suburb) }\end{array}$ & & & & & & & & & & & & & & & & & & & & \\
\hline ...in Rural Region & -0.109 & -2.85 & 0.146 & 2.84 & -0.074 & -2.56 & 0.113 & 2.18 & - & - & - & - & - & - & 0.099 & 1.17 & - & - & - & - \\
\hline ...in Town & -0.090 & -2.81 & 0.140 & 3.34 & - & - & - & - & - & - & - & - & -0.110 & -1.84 & 0.140 & 2.04 & - & - & - & - \\
\hline $\begin{array}{l}\text {...in Urban Region } \\
\text { Census Region } \\
\text { (Base ... in the Northeast) }\end{array}$ & - & - & -0.083 & -1.42 & - & - & - & - & - & - & - & - & - & - & - & - & - & - & -0.091 & -2.62 \\
\hline ...in the Midwest & -0.059 & -1.76 & - & - & -0.052 & -1.87 & 0.103 & 2.18 & - & - & - & - & - & - & - & - & -0.091 & -3.99 & 0.174 & 6.33 \\
\hline ...in the South & -0.411 & -10.54 & 0.493 & 11.80 & -0.239 & -7.51 & 0.552 & 10.92 & -0.536 & -8.50 & 0.587 & 8.84 & -0.669 & -8.84 & 0.736 & 10.02 & -0.422 & -17.06 & 0.631 & 21.53 \\
\hline ...in the West & -0.288 & -7.12 & 0.455 & 10.19 & -0.180 & -5.49 & 0.608 & 11.81 & -0.470 & -7.02 & 0.578 & 8.20 & -0.467 & -6.61 & 0.554 & 6.78 & -0.478 & -17.25 & 0.631 & 19.44 \\
\hline
\end{tabular}


Table 2: Leisure Activity Models Results (Continued)

\begin{tabular}{|c|c|c|c|c|c|c|c|c|c|c|c|c|c|c|c|c|c|c|c|c|}
\hline \multirow[b]{4}{*}{$\begin{array}{l}\text { Household Economic } \\
\text { Factors }\end{array}$} & \multicolumn{4}{|c|}{ Entertainment } & \multicolumn{4}{|c|}{ Recreation } & \multicolumn{4}{|c|}{ Resting } & \multicolumn{4}{|c|}{ Sightseeing } & \multicolumn{4}{|c|}{ Visiting } \\
\hline & \multicolumn{2}{|c|}{$\begin{array}{l}\text { Daily Short } \\
\text { Distance } \\
\text { Loyalty }\end{array}$} & \multicolumn{2}{|c|}{$\begin{array}{c}\text { Monthly } \\
\text { Long } \\
\text { Distance } \\
\text { Activities } \\
\end{array}$} & \multicolumn{2}{|c|}{$\begin{array}{l}\text { Daily Short } \\
\text { Distance } \\
\text { Loyalty }\end{array}$} & \multicolumn{2}{|c|}{$\begin{array}{l}\text { Monthly Long } \\
\text { Distance } \\
\text { Activities }\end{array}$} & \multicolumn{2}{|c|}{$\begin{array}{l}\text { Daily Short } \\
\text { Distance } \\
\text { Loyalty }\end{array}$} & \multicolumn{2}{|c|}{$\begin{array}{c}\text { Monthly Long } \\
\text { Distance } \\
\text { Activities }\end{array}$} & \multicolumn{2}{|c|}{$\begin{array}{l}\text { Daily Short } \\
\text { Distance } \\
\text { Loyalty }\end{array}$} & \multicolumn{2}{|c|}{$\begin{array}{c}\text { Monthly Long } \\
\text { Distance } \\
\text { Activities }\end{array}$} & \multicolumn{2}{|c|}{$\begin{array}{l}\text { Daily Short } \\
\text { Distance } \\
\text { Loyalty }\end{array}$} & \multicolumn{2}{|c|}{$\begin{array}{l}\text { Monthly Long } \\
\text { Distance } \\
\text { Activities }\end{array}$} \\
\hline & Coeff & t-stat & Coeff & t-stat & Coeff & t-stat & Coeff & t-stat & Coeff & t-stat & Coeff & t-stat & Coeff & t-stat & Coeff & t-stat & Coeff & t-stat & Coeff & t-stat \\
\hline & & & & & & & & & & & & & & & & & & & & \\
\hline \multicolumn{21}{|l|}{$\begin{array}{l}\text { Home Ownership } \\
\text { (Base: ...Provided by } \\
\quad \text { Someone Else) }\end{array}$} \\
\hline ...Owns home & -0.355 & -1.98 & - & - & - & - & - & - & - & - & - & - & - & - & -0.980 & -6.97 & 0.300 & 2.23 & -0.313 & -2.19 \\
\hline ...Rents home & -0.385 & -2.11 & - & - & - & - & - & - & - & - & - & - & - & - & -1.067 & -6.79 & 0.281 & 2.07 & -0.272 & -1.88 \\
\hline $\begin{array}{l}\text { Home Type } \\
\text { (Base: ...in Mobile } \\
\text { Home/Trailer/Other Accom.) }\end{array}$ & & & & & & & & & & & & & & & & & & & & \\
\hline ...in Single, Detached Home & - & - & - & - & - & - & -0.184 & -2.17 & 0.242 & 1.50 & - & - & - & - & - & - & -0.035 & -1.47 & 0.084 & 2.88 \\
\hline $\begin{array}{l}\text {...in Apartment, Duplex, or } \\
\text { Townhouse }\end{array}$ & - & - & - & - & - & - & -0.208 & -2.21 & 0.288 & 1.71 & -0.177 & -2.14 & 0.109 & 1.73 & - & - & - & - & - & - \\
\hline \multicolumn{21}{|l|}{$\begin{array}{l}\text { Household Annual Income } \\
\text { (Base: ...is less than } \\
\quad \$ 20,000)\end{array}$} \\
\hline $\begin{array}{l}\text {...is between } \$ 20,000 \text { and } \\
\$ 39,999\end{array}$ & - & - & 0.126 & 2.30 & -0.123 & -4.10 & 0.226 & 3.44 & - & - & - & - & - & - & - & - & - & - & 0.082 & 2.76 \\
\hline $\begin{array}{l}\text {...is between } \$ 40,000 \text { and } \\
\$ 59,999\end{array}$ & - & - & 0.143 & 2.60 & - & - & 0.167 & 2.61 & - & - & - & - & - & - & 0.122 & 1.71 & - & - & 0.154 & 5.09 \\
\hline $\begin{array}{l}\text {...is between } \$ 60,000 \text { and } \\
\$ 79,999\end{array}$ & - & - & 0.167 & 2.73 & 0.092 & 3.03 & 0.144 & 2.07 & - & - & - & - & - & - & 0.136 & 1.54 & -0.520 & -2.13 & 0.153 & 4.19 \\
\hline ...is greater than $\$ 80,000$ & - & - & 0.203 & 3.58 & 0.104 & 3.87 & 0.160 & 2.52 & - & - & 0.104 & 2.02 & - & - & 0.133 & 1.75 & -0.124 & -5.46 & 0.270 & 7.90 \\
\hline \multicolumn{21}{|l|}{$\begin{array}{l}\text { Household Telephone } \\
\text { Access }\end{array}$} \\
\hline $\begin{array}{l}\text { Number of Cell Phones in the } \\
\text { household }\end{array}$ & - & - & 0.029 & 1.89 & -0.020 & -1.92 & 0.028 & 1.73 & -0.025 & -1.25 & - & - & - & - & 0.530 & 2.03 & -0.023 & -2.68 & 0.046 & 4.30 \\
\hline \multicolumn{21}{|l|}{$\begin{array}{l}\text { Household Vehicle } \\
\text { Ownership }\end{array}$} \\
\hline $\begin{array}{l}\text { Number of Vehicles in the } \\
\text { household ( } 5 \text { max })\end{array}$ & - & - & - & - & -0.052 & -4.23 & 0.116 & 4.21 & - & - & - & - & - & - & - & - & - & - & - & - \\
\hline $\begin{array}{l}\text { Number of Bicycles in the } \\
\text { household ( } 5 \text { max })\end{array}$ & - & - & - & - & 0.059 & 7.33 & - & - & 0.029 & 1.71 & - & - & - & - & - & - & - & - & - & - \\
\hline
\end{tabular}


Table 2: Leisure Activity Models Results (Continued)

\begin{tabular}{|c|c|c|c|c|c|c|c|c|c|c|c|c|c|c|c|c|c|c|c|c|}
\hline \multirow[b]{4}{*}{ Household Demographics } & \multicolumn{4}{|c|}{ Entertainment } & \multicolumn{4}{|c|}{ Recreation } & \multicolumn{4}{|c|}{ Resting } & \multicolumn{4}{|c|}{ Sightseeing } & \multicolumn{4}{|c|}{ Visiting } \\
\hline & \multicolumn{2}{|c|}{$\begin{array}{l}\text { Daily Short } \\
\text { Distance } \\
\text { Loyalty } \\
\end{array}$} & \multicolumn{2}{|c|}{$\begin{array}{c}\text { Monthly Long } \\
\text { Distance } \\
\text { Activities }\end{array}$} & \multicolumn{2}{|c|}{$\begin{array}{l}\text { Daily Short } \\
\text { Distance } \\
\text { Loyalty }\end{array}$} & \multicolumn{2}{|c|}{$\begin{array}{c}\text { Monthly Long } \\
\text { Distance } \\
\text { Activities }\end{array}$} & \multicolumn{2}{|c|}{$\begin{array}{l}\text { Daily Short } \\
\text { Distance } \\
\text { Loyalty }\end{array}$} & \multicolumn{2}{|c|}{$\begin{array}{c}\text { Monthly Long } \\
\text { Distance } \\
\text { Activities }\end{array}$} & \multicolumn{2}{|c|}{$\begin{array}{l}\text { Daily Short } \\
\text { Distance } \\
\text { Loyalty }\end{array}$} & \multicolumn{2}{|c|}{$\begin{array}{c}\text { Monthly Long } \\
\text { Distance } \\
\text { Activities }\end{array}$} & \multicolumn{2}{|c|}{$\begin{array}{l}\text { Daily Short } \\
\text { Distance } \\
\text { Loyalty }\end{array}$} & \multicolumn{2}{|c|}{$\begin{array}{c}\text { Monthly Long } \\
\text { Distance } \\
\text { Activities }\end{array}$} \\
\hline & Coeff & t-stat & Coeff & t-stat & Coeff & t-stat & Coeff & t-stat & Coeff & t-stat & Coeff & t-stat & Coeff & t-stat & Coeff & t-stat & Coeff & t-stat & Coeff & t-stat \\
\hline & & & & & & & & & & & & & & & & & & & & \\
\hline \multicolumn{21}{|l|}{ Household Members } \\
\hline $\begin{array}{l}\text { Number of Adults in the } \\
\text { household ( } 5 \text { max })\end{array}$ & 0.090 & 4.93 & - & - & 0.170 & 8.15 & - & - & - & - & - & - & - & - & - & - & 0.131 & 10.04 & - & - \\
\hline $\begin{array}{l}\text { Number of Children in the } \\
\text { household ( } 5 \text { max) }\end{array}$ & 0.123 & 7.60 & -0.086 & -5.69 & 0.128 & 9.31 & - & - & 0.057 & 2.47 & - & - & 0.175 & 4.91 & -0.167 & -5.55 & 0.116 & 10.61 & - & - \\
\hline Number of Drivers ( 5 max $)$ & - & - & 0.062 & 2.41 & - & - & - & - & - & - & - & - & - & - & - & - & - & - & 0.081 & 4.02 \\
\hline Number of Workers (5 max) & - & - & -0.073 & -3.37 & -0.101 & -6.65 & -0.079 & -2.04 & - & - & - & - & -0.062 & -2.13 & - & - & - & - & -0.110 & -4.77 \\
\hline \multicolumn{21}{|l|}{$\begin{array}{l}\text { Lifecycle of Children } \\
\text { Within Household } \\
\text { (Base: ...has no children) }\end{array}$} \\
\hline $\begin{array}{l}\text {...has children, the youngest } \\
\text { of which is aged } 0-5\end{array}$ & 0.128 & 2.42 & - & - & 0.257 & 6.24 & - & - & 0.143 & 2.30 & - & - & 0.379 & 3.77 & - & - & 0.262 & 7.84 & - & - \\
\hline $\begin{array}{l}\text {...has children, the youngest } \\
\text { of which is aged 6-15 }\end{array}$ & 0.156 & 3.42 & - & - & 0.172 & 4.81 & - & - & - & - & - & - & 0.167 & 1.76 & - & - & 0.216 & 6.75 & -0.134 & -5.06 \\
\hline $\begin{array}{l}\text {...has children, the youngest } \\
\text { of which is aged } 16-21\end{array}$ & 0.047 & 1.02 & - & - & - & - & - & - & - & - & - & - & - & - & - & - & 0.202 & 5.78 & -0.131 & -3.19 \\
\hline \multicolumn{21}{|l|}{$\begin{array}{l}\text { Lifecycle of Adults Within } \\
\text { Household } \\
\text { (Base: ... is aged } 34 \text { or } \\
\quad \text { younger) }\end{array}$} \\
\hline$\ldots$ is aged $35-49$ & -0.059 & -1.69 & - & - & - & - & - & - & - & - & - & - & - & - & - & - & -0.042 & -1.84 & -0.081 & -3.48 \\
\hline$\ldots$ is aged $50-64$ & -0.066 & -1.66 & - & - & - & - & - & - & - & - & - & - & - & - & - & - & -0.066 & -2.62 & - & - \\
\hline$\ldots$ is aged 65 or older & -0.146 & -2.86 & 0.133 & 2.50 & 0.100 & 2.64 & -0.207 & -3.25 & - & - & - & - & - & - & - & - & -0.078 & -2.41 & - & - \\
\hline Household Comparisons & & & & & & & & & & & & & & & & & & & & \\
\hline $\begin{array}{l}\text { Ratio of Number of Drivers } \\
\text { to Number of Vehicles }\end{array}$ & - & - & - & - & - & - & -0.119 & -2.17 & - & - & - & - & - & - & - & - & 0.057 & 2.73 & -0.088 & -2.81 \\
\hline $\begin{array}{l}\text { Ratio of Number of Workers } \\
\text { to Number of Vehicles }\end{array}$ & - & - & - & - & - & - & 0.190 & 2.15 & - & - & - & - & - & - & - & - & -0.126 & -5.42 & 0.198 & 4.51 \\
\hline
\end{tabular}


Table 2: Leisure Activity Models Results (Continued)

\begin{tabular}{|c|c|c|c|c|c|c|c|c|c|c|c|c|c|c|c|c|c|c|c|c|}
\hline \multirow[b]{4}{*}{$\begin{array}{l}\text { Season of Year/ Day of } \\
\text { Week Variables }\end{array}$} & \multicolumn{4}{|c|}{ Entertainment } & \multicolumn{4}{|c|}{ Recreation } & \multicolumn{4}{|c|}{ Resting } & \multicolumn{4}{|c|}{ Sightseeing } & \multicolumn{4}{|c|}{ Visiting } \\
\hline & \multicolumn{2}{|c|}{$\begin{array}{l}\text { Daily Short } \\
\text { Distance } \\
\text { Loyalty }\end{array}$} & \multicolumn{2}{|c|}{$\begin{array}{l}\text { Monthly Long } \\
\text { Distance } \\
\text { Activities }\end{array}$} & \multicolumn{2}{|c|}{$\begin{array}{l}\text { Daily Short } \\
\text { Distance } \\
\text { Loyalty }\end{array}$} & \multicolumn{2}{|c|}{$\begin{array}{l}\text { Monthly Long } \\
\text { Distance } \\
\text { Activities }\end{array}$} & \multicolumn{2}{|c|}{$\begin{array}{l}\text { Daily Short } \\
\text { Distance } \\
\text { Loyalty }\end{array}$} & \multicolumn{2}{|c|}{$\begin{array}{c}\text { Monthly } \\
\text { Long } \\
\text { Distance } \\
\text { Activities } \\
\end{array}$} & \multicolumn{2}{|c|}{$\begin{array}{l}\text { Daily Short } \\
\text { Distance } \\
\text { Loyalty }\end{array}$} & \multicolumn{2}{|c|}{$\begin{array}{c}\text { Monthly } \\
\text { Long } \\
\text { Distance } \\
\text { Activities } \\
\end{array}$} & \multicolumn{2}{|c|}{$\begin{array}{l}\text { Daily Short } \\
\text { Distance } \\
\text { Loyalty }\end{array}$} & \multicolumn{2}{|c|}{$\begin{array}{c}\text { Monthly Long } \\
\text { Distance Activities }\end{array}$} \\
\hline & Coeff & t-stat & Coeff & t-stat & Coeff & t-stat & Coeff & t-stat & Coeff & t-stat & Coeff & t-stat & Coeff & t-stat & Coeff & t-stat & Coeff & t-stat & Coeff & t-stat \\
\hline & & & & & & & & & & & & & & & & & & & & \\
\hline $\begin{array}{l}\text { Household Travel Season } \\
\text { (Base: ...during Summer) }\end{array}$ & & & & & & & & & & & & & & & & & & & & \\
\hline ...during Fall & 0.118 & 3.83 & -0.128 & -3.06 & -0.113 & -3.02 & - & - & - & - & - & - & - & - & - & - & - & - & - & - \\
\hline ...during Winter & - & - & - & - & -0.126 & -2.95 & - & - & -0.130 & -1.73 & - & - & - & - & - & - & - & - & 0.105 & 4.01 \\
\hline $\begin{array}{l}\text {...during Spring } \\
\text { Household Travel Day } \\
\text { (Base: ...on Weekday) }\end{array}$ & - & - & - & - & -0.050 & -1.54 & - & - & -0.087 & -1.69 & - & - & -0.150 & -2.50 & 0.120 & 1.80 & -0.081 & -4.49 & 0.135 & 5.69 \\
\hline $\begin{array}{l}\text {...on Weekend } \\
\text { Impact of } \mathbf{9 / 1 1} \\
\text { (Base: ... before 9/11) }\end{array}$ & 0.203 & 8.49 & - & - & 0.097 & 4.36 & - & - & 0.125 & 2.83 & - & - & 0.110 & 2.17 & - & - & 0.262 & 16.62 & - & - \\
\hline$\ldots$ after $9 / 11$ & -0.128 & -4.86 & 0.173 & 5.02 & -0.036 & -1.18 & -0.100 & -2.93 & -0.209 & -3.82 & 0.201 & 3.77 & - & - & - & - & - & - & -0.062 & -2.78 \\
\hline Dependency Parameter $(\theta)$ & & -8.932 & $-50.94)$ & & & -5.732 & $-37.75)$ & & & -12.914 & $-34.78)$ & & & -14.574 & $-29.34)$ & & & -5.35 & $5(-64.28)$ & \\
\hline
\end{tabular}

